\title{
Celery petiole lesion damage caused by insecticide
}

Steven T. Koike $\square$ Richard F. Smith $\square$ Kurt F. Schulbach $\square$ William E. Chaney

\begin{abstract}
A previously undiagnosed problem, called celery petiole lesion (CPL), caused significant damage to coastal celery for several years. A 2-year study found CPL to be associated with applications of the insecticide Dibrom. The product is no longer labeled for use on celery. CPL can be mistaken for two fungal diseases, highlighting the importance of accurate diagnosis of plant problems to reduce unnecessary applications of pesticides.
\end{abstract}

Celery is an important vegetable crop grown in coastal California. In 1996, a six-county coastal region (Monterey, San Benito, San Luis Obispo, Santa Barbara, Santa Cruz and Ventura counties) produced 22,500 acres with a value of $\$ 232.5$ million. In addition to the value of the crop itself, celery is a rotation crop for the extensive crucifer and lettuce plantings in the coastal area. In recent years an undiagnosed problem, designated as celery petiole lesion (CPL), caused significant damage to celery crops and prevented some fields from being harvested for the fresh market.

Plants with typical CPL symptoms exhibit sunken, elongated, tan to brown, dry areas forming between the prominent vascular bundles on the lower portions of older petioles. Lesions can develop on both inner and outer surfaces of any individual petiole and characteristically lack the soft, rotted tissues associated, with most diseases. In severe cases the lesions occur on the younger as well as the older petioles. Applied fungicides did not alleviate the symptoms.

Field surveys showed that incidence of the problem in any one field ranged from slight (under 5\%) to widespread (over $90 \%$ ). CPL was most commonly found on celery produced in the Salinas Valley (Monterey County) and the San Benito area (San Benito County) during August through November. Early spring celery plantings did not exhibit CPL symptoms. The purpose of this study was to identify the cause of CPL.

\section{Testing for pathogenic organisms}

Because celery is susceptible to pathogenic fungi that cause lesions on the petioles, we collected CPL-affected plants from fields in the Salinas Valley in the summers of 1994 and 1995 and tested for pathogens. Small pieces from these petioles were washed, surface sterilized and aseptically placed on microbiological agar media. We incubated the plates at room temperature and identified the resulting fungal colonies.

We also tested CPL-affected petioles for possible bacterial pathogens. After petiole samples were surface sterilized, extracts from small pieces of tissue were streaked onto bacteriological agar media. Plates were incubated at room temperature and examined for bacterial growth.

Out of 200 (1994) and 100 (1995) fungal isolations, no pathogenic fungi were recovered from CPL-affected petioles. In particular, known pathogens such as Rhizoctonia solani and Sclerotinia sclerotiorum were never recovered, indicating that CPL was not caused by these organisms. Out of 100 (1994) and 80 (1995) bacterial isolations, few bacteria were recovered. Examination of representative bacterial strains indicated that they were not plant pathogenic species.

\section{Sidedress fertilizer applications}

In 1995, we applied different rates of a standard sidedress fertilizer to commercial celery in the Salinas Valley to determine whether this material could cause CPL. Treatments were applied during the months of August and September when CPL was typically observed. The experimental design was a randomized complete block with three replications. Each plot measured four beds wide (each bed was 40 inches center-to-center) by 50 feet long. Using a commercial tractormounted applicator, according to standard grower practice and timing, we injected sidedress applications of 1818-18 fertilizer into beds. Treatments were no sidedress applications $(0 x)$; two applications of $700 \mathrm{lb} /$ acre each (1x, considered to be the grower standard); and two applications of 1,000 $\mathrm{lb} /$ acre each (1.5x). At the end of the trial (Oct. 11), we evaluated 10 plants per plot for the presence or absence of CPL symptoms.

In all plots, typical CPL symptoms were absent. Small brown scars and marks, from undetermined causes, were present in all treatments. The absence of typical CPL symptoms and the most frequent occurrence of small brown defects in the $0 x$ treatment provided evidence that sidedress applications of fertilizer were not implicated in CPL development.

\section{Testing field-applied pesticides}

Because commercial celery plantings are treated with a variety of pesticides, in 1995 we tested nine commonly used materials for possible involvement with CPL. Celery (cv. Utah 52-70R) was transplanted on June 25 at an experimental plot in the Salinas Valley and grown according to standard commercial practice. Experimental design was a randomized complete block with three replications, with each plot measuring two beds wide (each bed was 40 inches center-to- 
center) by 30 feet long. Four insecticides (Agri-mek, Ambush, Dibrom, Lannate), three fungicides (Benlate, Bravo, Kocide), one foliar fertilizer (Folical) and one wetting agent (K-90 nonionic spreader) (table 1) were combined into one tank mix and applied as a foliar spray at label rates (1x) and double the label rates $(2 \mathrm{x})$ using a backpack $\mathrm{CO}_{2}$ sprayer. Materials were applied three times (Aug. 25, Sept. 19 and Oct. 5), and an untreated control was included. At the end of the trial (Oct. 30), we evaluated 10 plants per plot for CPL.

When the nine-chemical tank mix was sprayed onto celery, typical CPL symptoms resulted in both the $1 x$ and $2 x$ treatments, with $2 x$ plots having significantly more CPL lesions than $1 x$ plots (table 1). Symptoms on the $2 x$ treated plants were also significantly more severe than those on the $1 x$ plants. The untreated plots were either symptomless or had only a few small brown scars from undetermined causes. Treatment differences were statistically significant. This was the first indication that pesticides were implicated with CPL damage.

\section{Greenhouse experiments}

Following the successful reproduction of CPL symptoms in the 1995 field trial, we conducted a series of greenhouse experiments, each repeated a second time, to identify which material or materials might be involved in CPL damage.

In trial 1, each tank mix component of the 1995 field trial was prepared

TABLE 1. Effects of a nine-chemical tank mix on celery petiole lesion (CPL) incidence in the 1995 field experiment

\begin{tabular}{lc}
\hline \hline Treatment* & $\begin{array}{c}\text { Mean no. of CPL } \\
\text { petioles/10 plants } \dagger\end{array}$ \\
\hline Tank mix 1x & 8.14 \\
Tank mix 2x & 52.79 \\
Untreated & 0.50 \\
LSD $(P=0.05)$ & 4.54 \\
\hline
\end{tabular}

"Label (1x) rates/acre of the materials used in the tank mix were Agri-Mek 0.15 EC, 14.0 fl. oz; Ambush $25 \mathrm{~W}, 0.8 \mathrm{lb}$; Dibrom 8 F, 1.5 pt; Lannate WSP, $1.0 \mathrm{lb}$; Benlate $50 \mathrm{WP}, 0.5 \mathrm{lb}$; Bravo 500, 4.0 pt; Kocide 101, $2.0 \mathrm{lb}$; Folical, 2.0 pt; K-90, 0.25 pt. $2 x$ rates are double the label rates.

tThe number of CPL-affected petioles per 10 plants was calculated, and ANOVA conducted with MSTAT-C statistical program separately and applied to young celery transplants to test for phytotoxicity. Experimental design was a randomized complete block with three replications. Each block consisted of 40 celery transplants, in transplant trays ( 1 by 1 inch cells), that were of transplantready maturity. Materials were applied separately to different sets of plants as one-time drench treatments (in 1 quart water per three replications) at label rates (1x) and double the label rates (2x). A water control was included. Drenches were designed to result in overdose levels so that CPL damage might be accentuated. After 1 week, we examined the plants for phytotoxic symptoms.

In trial 2, the seven materials that did not cause phytotoxic damage in greenhouse trial 1 (all chemicals except Dibrom and Lannate) were combined into one drench solution to further show their lack of association with CPL. Experimental design and treatment concentrations and volumes were the same as in trial 1 , and we again applied treatments one time as drench treatments. Plants were subsequently examined for phytotoxicity.

We conducted all remaining greenhouse experiments using only Dibrom and Lannate. Trial 3 evaluated the effects of different Dibrom and Lannate rates in relation to CPL. Experimental design was a randomized complete block with three replications. Each block consisted of 10 celery plants planted individually in 4-inch-square pots (mature transplants were placed into the pots and allowed to grow for approximately 3 weeks before treating with chemicals). Using the label rate as the $1 x$ concentration (1.5 pt Dibrom / acre, $1.0 \mathrm{lb}$ Lannate /acre; 100 gal water/acre), the following mixtures were prepared for each insecticide: $0.25 x$, $0.50 x, 1 x, 2 x$ and $3 x$. We applied approximately 5 drops of solution via pipette to the crown of each plant, twice within a 10-day period, and a water control was included. Two weeks after the second treatment, we examined plants for CPL symptoms and rated them for severity using the following scale: 1 = absence of any symptoms; 2 = slight CPL (minor discoloration of petiole epidermis and/or develop-
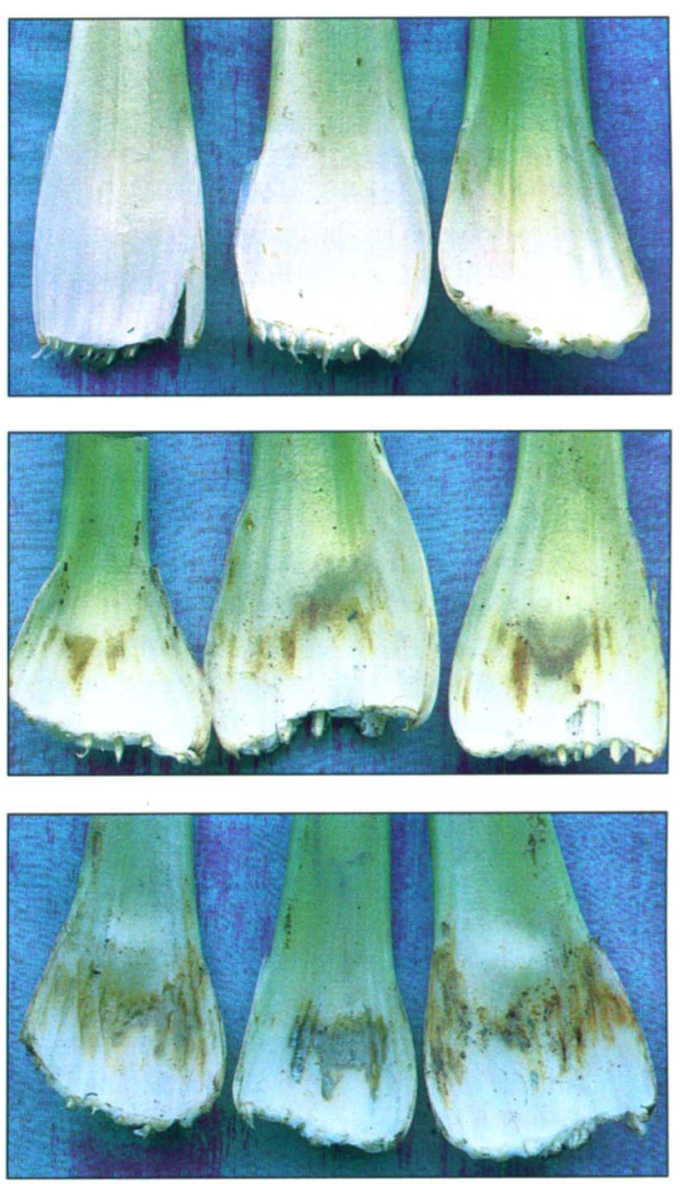

CPL was absent on untreated field plants (top), but developed on plants treated with low (middle) and high (bottom) concentrations of the pesticide tank mix. Plants receiving the higher rate developed more severe symptoms.

ment of shallow lesions); 3 = moderate CPL (tan to light brown discoloration of epidermis and development of sunken lesions); 4 = severe CPL (dark brown discoloration of epidermis and development of deep, sunken lesions).

Using the same experimental parameters as in trial 3, in trial 4 we evaluated the reaction of two celery cultivars to Dibrom concentrations. Using the label rate as the $1 x$ concentration, the following Dibrom solutions were prepared: $0.50 \mathrm{x}, 1 \mathrm{x}$ and $2 \mathrm{x}$. we applied approximately 5 drops of solution via pipette to the crown of each plant of cultivar 52-75, a celery variety used for many years, and of Conquistador, a more recently released variety. Treatments were applied twice within a 10 -day period, 
and a water control was included. Two weeks after the second treatment, we examined and rated plants for CPL.

\section{Two chemicals harm celery}

Of the nine chemicals and water control used in trial 1, only Dibrom and Lannate caused phytotoxicity (table 2). Dibrom damage consisted of brown discoloration and burning of plant crowns and lower petioles. Lannate treatments resulted in burned and desiccated leaves. For Dibrom, the $2 x$ concentrations resulted in greater phytotoxic effects than the $1 x$ treatment.

In trial 2, Dibrom and Lannate again caused phytotoxicity, and symptoms were identical to those in trial 1 (table 2). Dibrom treatments exhibited greater phytotoxicity with the $2 x$ concentration than with the $1 x$ treatment. The seven-component tank mix drench did not cause any plant damage at either $1 x$ or $2 x$ concentration.

In trial 3, Lannate applied to plant crowns did not cause CPL symptoms and showed no other phytotoxic effects on the celery plants (table 3 ). Lannate was therefore eliminated as a possible cause of CPL and was not included in the statistical analysis. However, Dibrom caused slight but typical CPL symptoms at $0.25 x$ and $0.50 x$, moderate to severe CPL at $1 x$, and severe CPL at $2 x$ and $3 x$ (table 3 ). The water control did not result in any

TABLE 2. Greenhouse trials 1 and 2. Phytotoxic effects of drench applications of nine chemicals on greenhouse celery transplants

\begin{tabular}{|c|c|c|c|}
\hline \multirow[b]{3}{*}{ Trial } & \multirow[b]{3}{*}{ Treatment* } & \multirow{2}{*}{\multicolumn{2}{|c|}{$\begin{array}{c}\text { Severity of phyto- } \\
\text { toxic symptoms } \\
\text { Rates/acre }\end{array}$}} \\
\hline & & & \\
\hline & & $1 x$ & $2 x$ \\
\hline . & $\begin{array}{l}\text { Agri-Mek } 0.15 \mathrm{EC}, 14.0 \mathrm{fl} . \mathrm{oz} \\
\text { Ambush } 25 \mathrm{~W}, 0.8 \mathrm{lb} \\
\text { Dibrom } 8 \mathrm{~F}, 1.5 \mathrm{pt} \\
\text { Lannate WSP, } 1.0 \mathrm{lb} \\
\text { Benlate } 50 \mathrm{WP}, 0.5 \mathrm{lb} \\
\text { Bravo } 500,4.0 \mathrm{pt} \\
\text { Kocide } 101,2.0 \mathrm{lb} \\
\text { Folical, } 2.0 \mathrm{pt} \\
\text { K-90, } 0.25 \mathrm{pt} \\
\text { Water control }\end{array}$ & $\begin{array}{l}- \\
- \\
+ \\
+ \\
- \\
- \\
- \\
-\end{array}$ & $\begin{array}{l}- \\
- \\
++ \\
+ \\
- \\
- \\
- \\
-\end{array}$ \\
\hline 2 & $\begin{array}{l}\text { Tank mix } \dagger \\
\text { Dibrom } \\
\text { Lannate } \\
\text { Water control }\end{array}$ & $\begin{array}{l}- \\
+ \\
+ \\
-\end{array}$ & $\begin{array}{l}- \\
++ \\
+ \\
-\end{array}$ \\
\hline $\begin{array}{l}{ }^{\star} \text { Rati } \\
\text { mode } \\
\dagger \text { Tan } \\
\text { Ambi } \\
\text { nonio }\end{array}$ & $\begin{array}{l}\text { ting system: }-=\text { no phytotoxi } \\
\text { lerate symptoms; ++= severe } \\
\text { nk mix in trial } 2 \text { was composed } \\
\text { oush, Benlate, Bravo, Kocide, } \\
\text { onic spreader. }\end{array}$ & $\begin{array}{l}\text { c sym } \\
\text { symp } \\
\text { of } A \\
\text { Folical }\end{array}$ & $\begin{array}{l}+= \\
k \\
k-90\end{array}$ \\
\hline
\end{tabular}

CPL symptoms. A rate response was demonstrated with Dibrom, and treatment differences were statistically significant.

In trial 4, no significant differences in CPL severity were observed between the Conquistador and 52-75 cultivars (table 4). On both cultivars, Dibrom caused slight but typical CPL symptoms at $0.50 \mathrm{x}$, moderate CPL at $1 x$, and severe CPL at $2 x$. The water control did not result in CPL.

\section{Second field experiment}

To test our greenhouse findings under field conditions, we conducted a field experiment in 1996 to determine if early (6-8 inches high), middle (1214 inches), or late (16-20 inches) stages of growth were differentially sensitive to Dibrom. Celery was transplanted on June 28 into a split-plot experimental design with randomized complete blocks and four replications. Each plot measured two beds wide by 15 feet long and was planted with cv. Utah 52-70R on one bed and cV. Conquistador on the other to further explore varietal differences in susceptibility.

The label rate $(1 \mathrm{x}=1.5 \mathrm{pt} / \mathrm{acre})$ and double the label rate $(2 x=3.0 \mathrm{pt} /$ acre $)$ of Dibrom were applied using a backpack $\mathrm{CO}_{2}$ sprayer in 109 gal water / acre (for early growth-stage celery) or 179 gal water/acre (for middle and late-growth-stage celery). All Dibrom treatments were mixed with $X-77$ spreader sticker ( $0.25 \mathrm{pt} / 100$ gal water). At the end of the trial (Oct. 17), we rated six plants per plot for CPL severity using the scale described previously.

Typical CPL symptoms were found in all Dibrom-treated plots, whereas the untreated control had only a few brown defects from undetermined causes (table 5). Dibrom $2 x$ caused significantly more CPL than Dibrom $1 x$ in all treatments except the early treatment. For the $1 x$ treatments, there were no significant differences between the various timed applications; however, for $2 x$ treatments, earlymiddle-late and late sprays had significantly more CPL than early and middle sprays.

In general, the two cultivars did not differ significantly in their response to the Dibrom sprays. Only in treatment
6 (Dibrom 1x, early-middle), did one cultivar (Conquistador) have significantly more CPL than the other (Utah 52-70R).

\section{Commercial field surveys}

To document the association of CPL occurrence in commercial fields with the application of Dibrom, we conducted a survey in which we examined spray records for CPL-affected fields. For the 15 fields with CPL surveyed in 1994 and 1995, all had received ground applications of Dibrom.

As a result of our research, the celery label for this product was withdrawn and no Dibrom was applied to celery in California in 1996 and 1997. CPL damage was not reported in any county in California for the 1996 and 1997 seasons. Because of the complete absence of CPL reports in both 1996 and 1997, we examined 15 randomly chosen fields in locations previously affected by the problem and found no CPL in any of these locations.

\section{Dibrom associated with CPL}

Our 2-year investigation conclusively associated ground applications of the insecticide Dibrom with celery petiole lesion. In both field and greenhouse studies, applications of Dibrom consistently resulted in damaged petioles that were very similar to those observed in commercial fields. Even when applied at one-fourth and onehalf the recommended rate, Dibrom resulted in CPL on greenhouse-grown celery. Eight other commonly applied chemical products did not cause CPL when applied at excessively high concentrations. Extensive testing for pathogenic organisms failed to find any biotic agent associated with CPL, and a field fertilizer experiment did not reproduce CPL symptoms.

Greenhouse and field experiments showed that CPL is apparently not related to differential sensitivities between cultivars. In addition, field surveys showed that numerous celery cultivars developed CPL (cvs. Matador, Summit, and several proprietary varieties), indicating that cultivar sensitivity is not a critical factor in CPL.

The 1996 field study indicated that label rates of Dibrom would not result 
in visible damage by harvest if applied early in crop development. However, CPL problems would increase due to applications made to middle and late stages of growth or from the effects of multiple sprays.

Field surveys in both 1994 and 1995 supported the field and greenhouse studies by showing a consistent association between commercial fields with CPL and ground applications of Dibrom. The 1996 and 1997 surveys further supported this finding in that no Dibrom was applied during these years and no CPL was observed. In addition, the UC Cooperative Extension Diagnostic Laboratory, located in Salinas, received no CPL samples in 1996 and 1997. This was in sharp contrast to the previous two years, during which CPL samples were often submitted during the period from August through November.

Although pathogenic fungi were not associated with CPL, symptomatology of two fungal diseases could be mistaken for CPL. Crater spot, caused by Rhizoctonia solani, generally causes sunken, brown cavities on the petioles exposed to soil. Occurring on the inner and outer petiole surfaces, crater spot infections vary in shape but generally have rounded edges, unlike the usually linear, rectangular CPL lesions. Like CPL, however, crater spot lesions are dry and firm in texture and might be mistaken for CPL.

In contrast, pink rot, caused by Sclerotinia sclerotiorum, results in soft, mushy infections at petiole bases or higher up in the plant canopy. Pink rot infections initially cause the celery tissue to turn pink, but older infections can be dark brown or black in color. For crater spot and pink rot, the mycelia of both causal organisms are usually present in the affected tissue, and laboratory analyses can readily recover the fungi. Our findings highlight the importance of accurate diagnosis of plant problems so that unnecessary pesticide applications are not made to crops affected by abiotic disorders.

We therefore conclude that "celery petiole lesion" should be designated as phytotoxicity due to Dibrom sprays applied by ground equipment. It is notable that in fields where Dibrom was applied via aircraft, no CPL was observed, hinting that water volume and crop coverage may be involved in CPL development. Insecticide sprays applied by ground equipment (typically using from 200 to 250 gal water/acre) result in pooling and accumulation of spray liquids at the base of celery petioles; this accumulation does not occur with air-applied materials (applied in 7 to $35 \mathrm{gal} /$ acre). Dibrom was used on celery to control the adult stage of the pea leafminer, Liriomyza huidobrensis, which in the past 5 years reached devastating levels in the Salinas Valley and resulted in significant quality and yield loss for celery, lettuce, spinach and other leafy vegetables. Dibrom continues to be applied to other vegetable crops in California, but it has not appeared to cause phytotoxic damage to these plants.

Our findings regarding Dibrom and CPL raise the question of why phytotoxicity to celery developed only recently. Dibrom has been applied to

TABLE 3. Greenhouse trial 3. Effects of various Dibrom and Lannate concentrations on celery petiole lesion (CPL) severity

\begin{tabular}{llc}
\hline \hline Treatment & Rates/acre & Mean CPL severity rating* \\
\hline Dibrom & $0.4 \mathrm{pt}(0.25 \mathrm{x})$ & 1.21 \\
Dibrom & $0.8 \mathrm{pt}(0.50 \mathrm{x})$ & 1.79 \\
Dibrom & $1.5 \mathrm{pt} \mathrm{(1x)}$ & 3.54 \\
Dibrom & $3.0 \mathrm{pt}(2 \mathrm{x})$ & 4.00 \\
Dibrom & $4.5 \mathrm{pt} \mathrm{(3x)}$ & 4.00 \\
Water & - & 1.00 \\
Lannate & 0.3 to $3.0 \mathrm{lb}(0.25 \mathrm{x}-3 \mathrm{x})$ & $1.00 \dagger$ \\
LSD $(P=0.05)$ & & 0.27 \\
\hline
\end{tabular}

"CPL damage was rated using the following scale: 1 = absence of any symptoms; 2 = slight CPL (minor discoloration of petiole epidermis and/or development of shallow lesions); $3=$ moderate CPL (tan to light brown discoloration of epidermis and development of sunken lesions); $4=$ severe CPL (dark brown discoloration of epidermis and development of deep, sunken lesions). ANOVA was conducted with MSTAT-C statistical program.

†Lannate values were not included in the statistical analysis.

TABLE 4. Greenhouse trial 4. Effects of Dibrom concentrations on celery petiole lesion (CPL) severity on two celery cultivars

\begin{tabular}{|c|c|c|c|}
\hline \multirow[b]{2}{*}{ Treatment } & \multirow[b]{2}{*}{ Rates/acre } & \multicolumn{2}{|c|}{$\frac{\text { Mean CPL severity rating }}{\text { Celery cultivar }}$} \\
\hline & & Conquistador & $52-75$ \\
\hline Dibrom & $0.8 \mathrm{pt}(0.50 \mathrm{x})$ & 1.76 & 1.53 \\
\hline Dibrom & $1.5 \mathrm{pt}(1 \mathrm{x})$ & 2.76 & 2.76 \\
\hline Dibrom & $3.0 \mathrm{pt}(2 x)$ & 4.00 & 4.00 \\
\hline Water & - & 1.00 & 1.00 \\
\hline
\end{tabular}

${ }^{*} \mathrm{CPL}$ damage was rated using the following scale: $1=$ no CPL (absence of any symptoms); 2 = slight CPL (minor discoloration of petiole epidermis and/or development of shallow lesions); $3=$ moderate CPL (tan to light brown discoloration of epidermis and development of sunken lesions); 4 = severe CPL (dark brown discoloration of epidermis and development of deep, sunken lesions). ANOVA was conducted with MSTAT-C statistical program. No significant differences were found between the two cultivars.

TABLE 5. 1996 field experiment. Effects of Dibrom on celery petiole lesion (CPL) severity when applied to two celery cultivars at early, middle and late stages of celery development

\begin{tabular}{lcc}
\hline \hline & \multicolumn{2}{c}{ Mean number of CPL petioles/6 plants } \\
\cline { 2 - 3 } & \multicolumn{2}{c}{ Celery cultivar } \\
\hline Treatment & Utah 52-70R & Conquistador \\
1. Untreated control & 0.00 & 1.50 \\
2. Dibrom 1x - early-middle-late & 5.25 & 6.75 \\
3. Dibrom 1x - early & 1.25 & 1.50 \\
4. Dibrom 1x - middle & 3.25 & 5.00 \\
5. Dibrom 1x - late & 3.75 & 4.00 \\
6. Dibrom 1X - early-middlet & 1.00 & 6.00 \\
7. Dibrom 2x - early-middle-late & 35.75 & 41.00 \\
8. Dibrom 2x - early & 2.00 & 3.25 \\
9. Dibrom 2x - middle & 11.75 & 11.50 \\
10. Dibrom 2x - late & 40.25 & 42.00 \\
LSD (P = 0.05) & 5.00 & 6.31 \\
\hline
\end{tabular}

*ANOVA was conducted with MSTAT-C statistical program.

tIndicates a significant difference between the two cultivars $(\operatorname{LSD}[P=0.05]=4.11)$. 


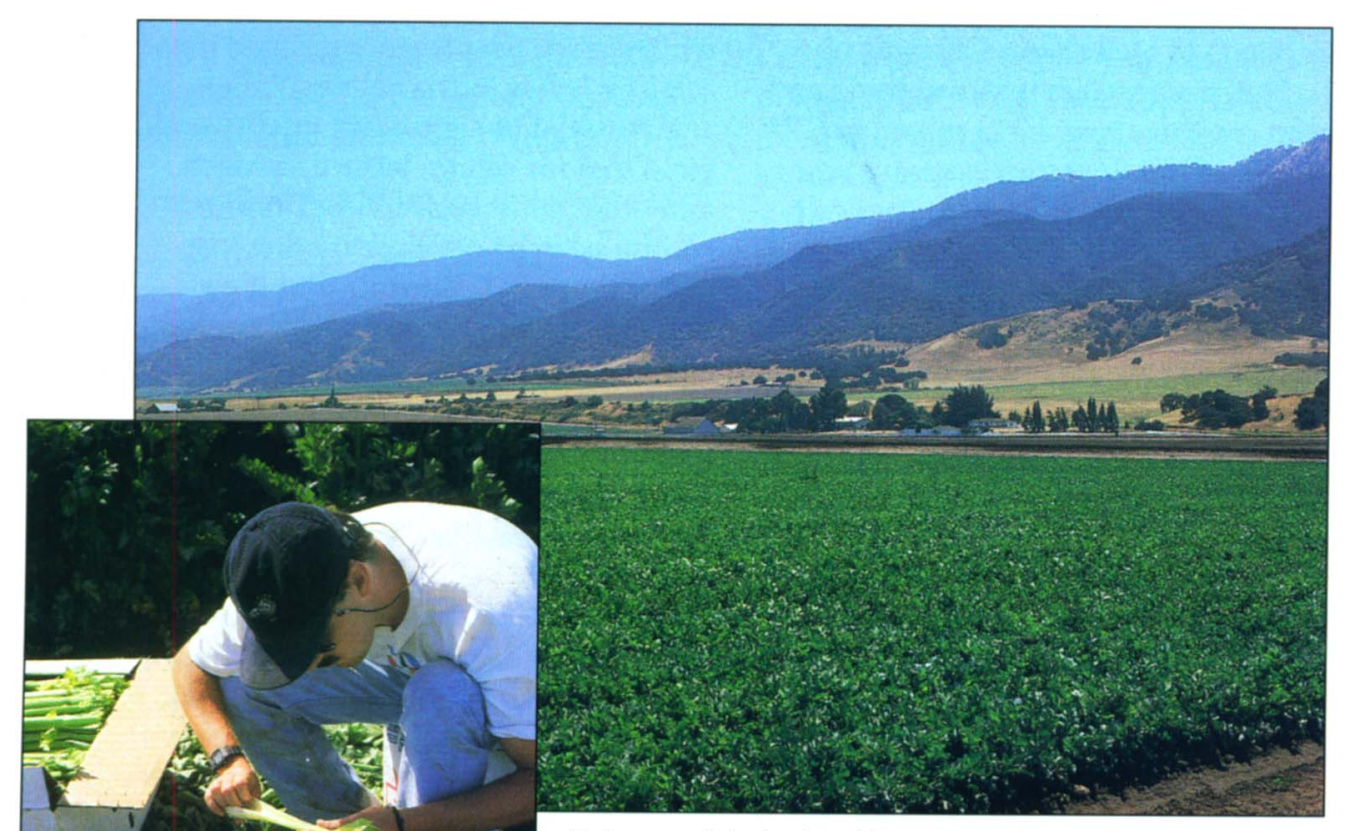

Celery petiole lesion (CPL) was most commonly found on celery produced in the Salinas Valley (shown above) and the San Benito area during August through November. This study revealed the association between the pesticide Dibrom and CPL. Inset, agricultural technician Evan Oakes inspects celery for symptoms of celery petiole lesion.

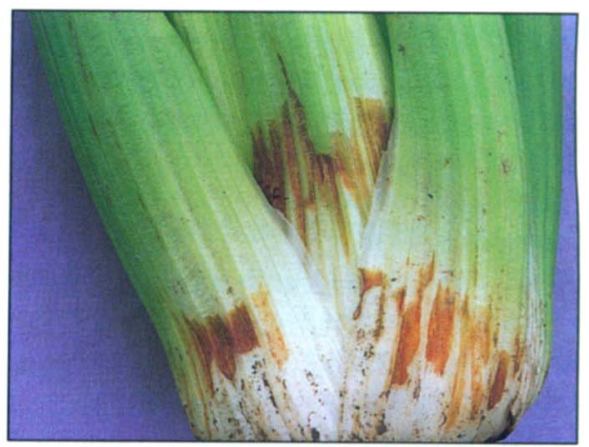

Celery petiole lesion symptoms consist of elongated, brown lesions forming between the vascular bundles on the lower petioles.

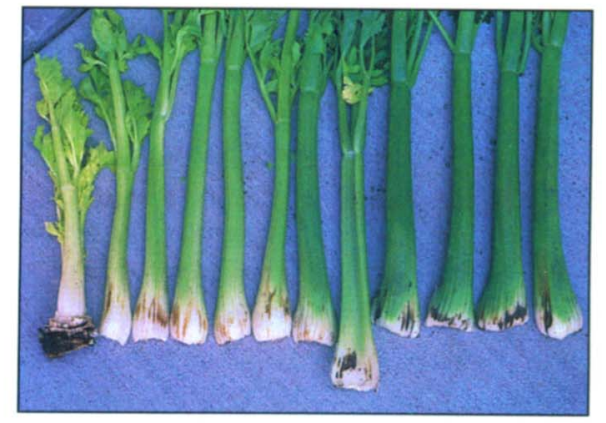

Celery petiole lesion can develop on both older and younger petioles.

T.G. Gonzalez, D.M. Henderson and E.D. Oakes. We acknowledge the celery industry in California and the California Celery Research Advisory Board for their support of this work, and thank the following individuals for their help: $F$. Alexander, D. Celis, J. Dow, B. Gray, A. Greathead, $H$. Kinnaman, M. Lamb, S. Lanini, W. Maitoza, M. McBride, E. Mora, M. Mulanax, A.O. Paulus, B. Riddle, J. Romans, B. Stickles and H. Yamaoka. We thank Hartnell College for the use of their East Campus field facility.

\section{CALIFORNIA AGRICULTURE ASSOCIATE EDITORS}

Animal, Avian, Aquaculture \& Veterinary Sciences Christopher M. Dewees

Kathryn Radke

Bennie I. Osburn

Barbara A. Reed

Economics \& Public Policy

Richard A. Howitt

Alvin Sokolow

Food \& Nutrition

Barbara O. Schneeman

Eunice Williamson
Human \& Community

\section{Development}

Linda M. Manton

Karen $P$. Varcoe

Land, Air \& Water Sciences

Garrison Sposito

Henry J. Vaux, Jr.

Natural Resources

Barbara H. Allen-Diaz

Daniel W. Anderson

Richard B. Standiford
Pest Management

Edward G. Platzer

Joseph G. Hancock, Jr

Michael K. Rust

Plant Sciences

Jodie S. Holt

Lee F. Jackson

G. Steven Sibbett http://danr.ucop.edu/calag/

CALAG@ucop.edu

PH: 510 987-0044

FAX: $510465-2659$ 